Article

\title{
Energy Transition in the Nebular City: Connecting Transition Thinking, Metabolism Studies, and Urban Design
}

\author{
Griet Juwet* (D) and Michael Ryckewaert ${ }^{(\mathbb{D}}$ \\ Cosmopolis Centre for Urban Research, Department of Geography, Vrije Universiteit Brussel, Pleinlaan 2, \\ BE-1050 Brussels, Belgium; michael.ryckewaert@vub.be \\ * Correspondence: griet.juwet@vub.be; Tel.: +32-(0)2-629-2828
}

Received: 29 January 2018; Accepted: 22 March 2018; Published: 25 March 2018

\begin{abstract}
Transforming urban infrastructures is an essential part of creating more sustainable urban regions. But rethinking these complex systems requires a better understanding of their spatial dimensions and their relation with urban morphology and spatial structure. This paper addresses that gap by examining different conceptualizations of technical infrastructure and space in science, technology and society studies (STS), transition thinking, urban metabolism studies, and urban political ecology, and draws connections with the spatial perspective of urban planning and design. It illustrates and tests these concepts through the case of energy transition in the Flemish region of Belgium. Transport and supply networks have played a crucial role in facilitating, structuring, and reproducing the region's characteristic dispersed and energy-intensive urban landscape. Bringing different disciplinary perspectives together, the research broadens the conceptualization of the spatial dimension in transition thinking, and identifies useful concepts and design parameters for urban design to engage with the technical and socio-political complexity of transforming urban infrastructure. It reveals the energy transition as an inherently spatial project, and explores the spatially and socio-politically transformative potential of the transition towards a new energy system.
\end{abstract}

Keywords: energy transition; urban metabolism; urban design; dispersed urbanization

\section{Introduction}

Contemporary life is unimaginable without a continuous supply of energy. But in the context of climate change and finite fossil fuel resources, existing energy systems need to be fundamentally rethought. Such systemic challenges related to technical infrastructures become most visible in urbanized regions, but it is also there that potential alternatives might take shape. This essential role of cities in (energy) infrastructure transformation is also recognized and mobilized in international partnerships and policies such as Habitat III and the Covenant of Mayors [1-3].

The relation between these networked infrastructures and urban transformation has become a shared concern between different disciplinary fields, such as transition studies (TS), urban metabolism studies (UM), and urban design (UD) [4-10]. However, what remains underexplored in TS and UM is how change in socio-technical systems and metabolic flows relates to the physical morphology and materiality of urban space. This relation works in two ways: how do transitions in socio-technical systems shape space, and how does a particular spatial context impact infrastructural transformations and sustainability transitions?

Urban design, on the other hand, has traditionally viewed infrastructure as a means to (re-)shape cities and territories. This approach was epitomized in iconic projects such as Haussmann's Paris, 
Cerdà's Barcelona, or Frank Lloyd Wright's Broadacre City [11]. From that perspective, the introduction of new infrastructures in the context of energy transitions can be framed as a fundamentally spatial project.

This paper draws connections between the conceptualization of technical infrastructure and space in TS and UM, and the spatial perspective of UD. It broadens the theoretical understanding of the spatial dimensions in transition and metabolism studies. It also aims to provide context for concepts such as 'transition' and 'urban metabolism' currently adopted in UD discourse and practice, often without fully understanding their theoretical depth and lineage. Connecting these different disciplinary perspectives, this paper develops a conceptual framework to study the transformation of technical systems in relation to urban morphology.

The case of energy transition in the dispersedly urbanized landscape of Flanders, the northern region of Belgium, is used to identify relevant concepts that emerge in the discourse surrounding urban design and energy transition projects. In these practices, the interdependency between energy transitions and processes of urbanization is revealed, but it also becomes clear that a fair amount of discrepancy exists between the operationalization of similar concepts in the 'technical' energy sector, the urban design discipline, and transition (management) approaches. The aim of the framework developed in this paper is to provide a hypothesis of interconnected concepts that can lead to a shared language on spatial energy transition projects between the technical, urban design, and transition disciplines. This framework and its interconnected concepts will be further tested in ulterior in-depth case study research focusing on collective heating systems in a Flemish city.

Introduction of the Case: Energy Transition in the Dispersed Landscape of Flanders

To illustrate how a particular form of urbanization matters for the transformation of an energy system, this paper will discuss the case of Flanders' dispersed urban landscape. It combines literature about the origins and mechanisms that have produced this particular spatial structure, with empirical research about the state of the art of energy policy, spatial planning, and energy transition practices in the region.

Transport and supply networks have played a crucial role in facilitating, structuring, and reproducing Flanders' 'nebular' spatial structure [12-15]. As shown in Figure 1, the region is characterized by a dispersed built-up area, serviced by dense transport infrastructure, supply networks, and services. This form of urbanization is increasingly recognized as fundamentally unsustainable for various reasons [16]. Dispersed urbanization creates a high energy demand for transport [17] and raises the societal cost of supply networks. Heat demand is also relatively high in Flanders, with a relatively old housing stock dominated by relatively large detached and semi-detached housing, often on suburban locations [18-20]. Renovation of the existing housing stock is complex due to the dominance of individual home ownership, and goes slowly with a yearly renovation rate of around $1 \%$ [21]. In the spatially fragmented landscape, available space for the integration of large new energy infrastructures is limited and contested.

A sustainability transition in the Flemish energy system, therefore, has a double spatial dimension: integrating new infrastructures for the production, conversion, and distribution of electricity, heat, and fuels requires space, and reducing energy demand calls for more energy-efficient buildings and urban structures. Planning research has focused on energy production, analyzing the landscape potential for renewable energy, usually on a regional scale [22,23]. On the other hand, energy efficiency policy has focused on the scale of appliances and individual buildings, but rarely approaches energy demand reduction on an urban or collective scale [24]. Recently, the relation between energy and spatial structure, and between improving the energy efficiency of the built environment and the transformation of energy production, has received more attention in policy debate $[25,26]$. Energy is no longer framed merely as an 'engineering question', but as an important spatial project, recognizing that a region's energy system and spatial structure are interdependent $[27,28]$. However, strategies to rethink existing spatial structures, or a critical perspective on the socio-political struggles inherent in 
such fundamental societal and spatial transformations, often remain absent. Based on the literature review and the case study, this paper therefore proposes a conceptual framework including relevant design parameters for spatial planning and design to engage with these systemic and socio-political dimensions of (energy) transitions.

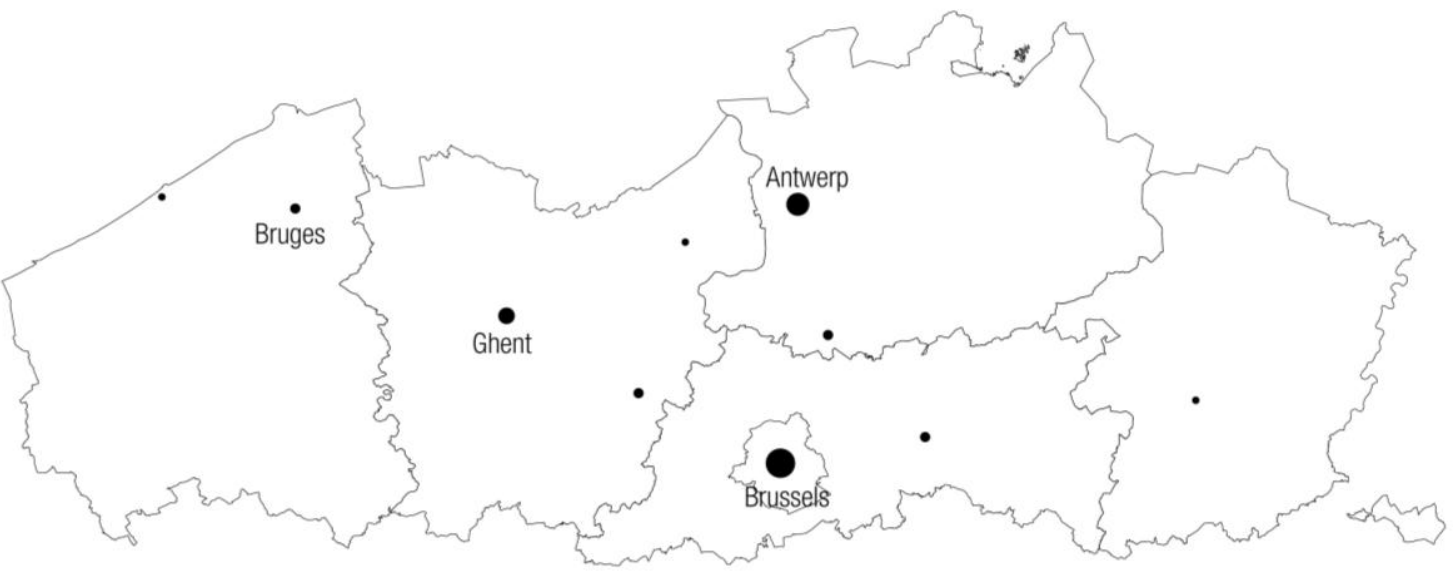

(a)

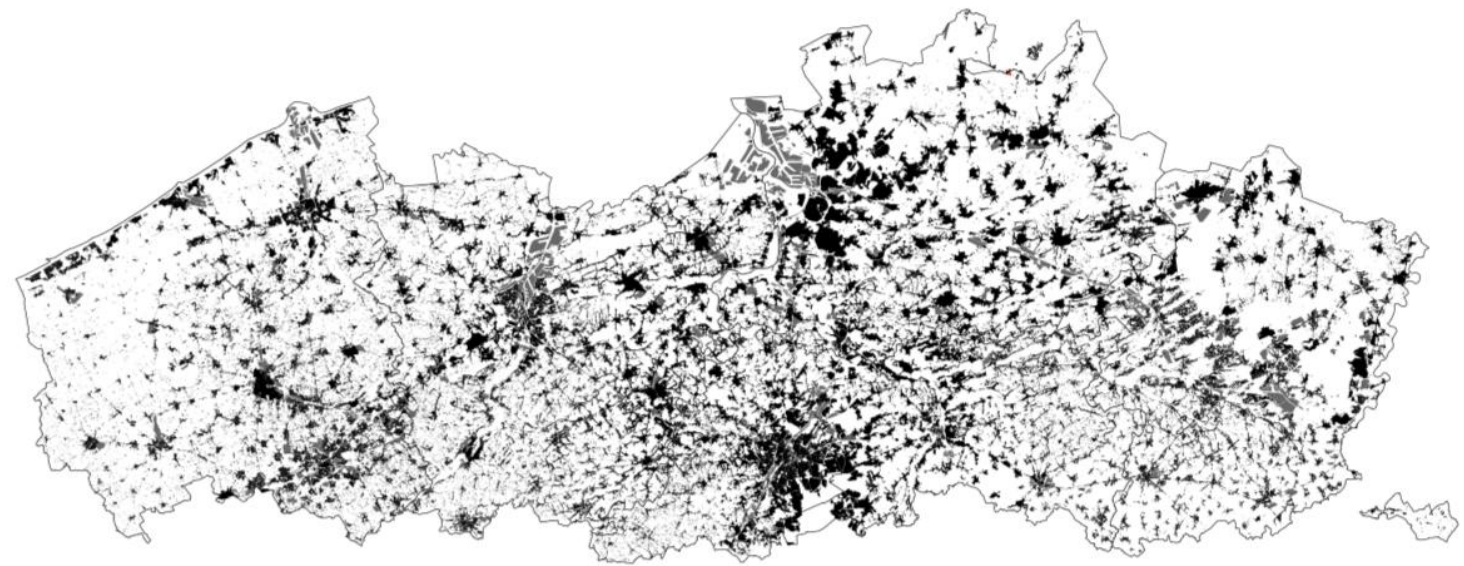

(b)

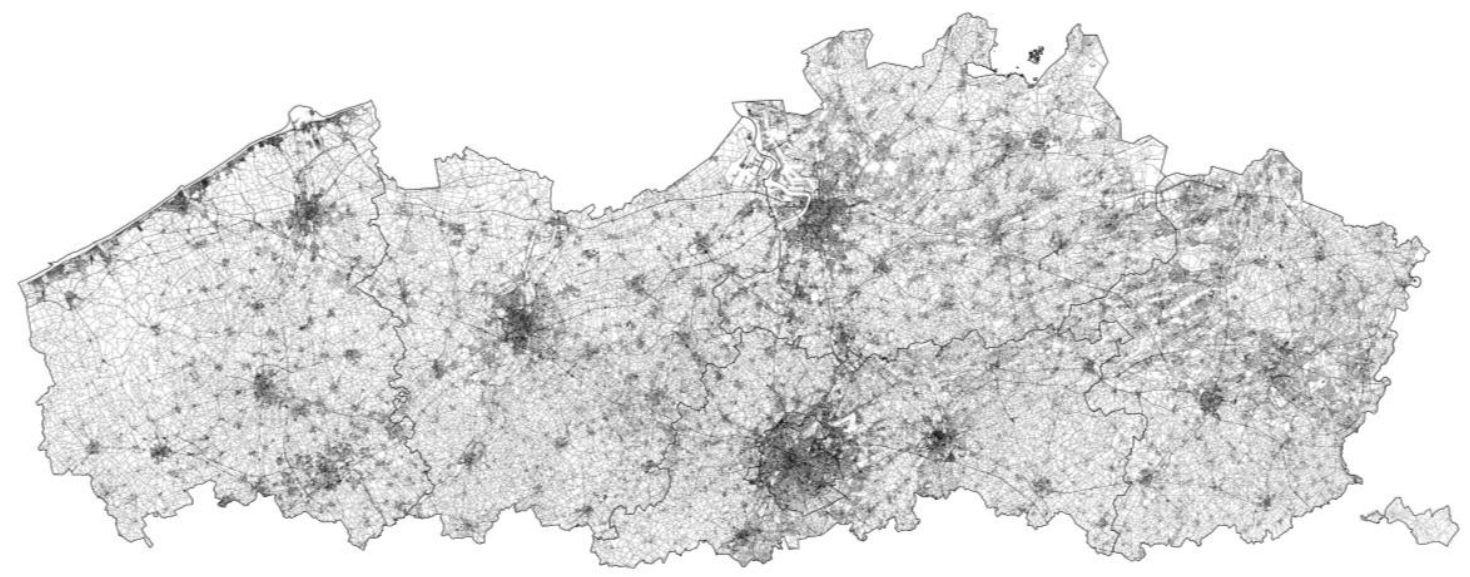

(c)

Figure 1. Spatial structure of Flanders. (a) location of the main cities, (b) dispersed and sprawling built-up area, (c) isotropic street network (data (c) Open Street Map and AGIV). 


\section{Materials and Methods}

This paper combines an exploratory literature review with empirical research about the case of energy transition in the Flemish region. The literature review explores transition studies (TS), urban metabolism studies (UM), and urban design theory (UD), but also draws on broader material from science, technology and society studies (STS) and urban political ecology (UPE). It focuses on literature that engages with the relation between physical infrastructure, urban space, and social change, and on UD theory particularly related with contexts of dispersed urbanization. The research highlights the transformation of the energy system as a shared concern between these different disciplines, drawing conceptual connections but also identifying tensions and gaps in how these fields conceptualize infrastructures and spatial change.

The case study research involved a review of relevant policy and design studies for energy transition in the Flemish region, and a thorough screening of recent and ongoing practices in the domain of energy transition and urban design. This included diverse projects such as the extension of existing district heating networks, the integration of collective heating systems in new sustainable urban developments, the construction of large-scale renewable energy production infrastructure, the integration of small-scale solar energy on a household level, collective renovation and solar energy production projects by citizen energy cooperatives, etc. These practices were documented through interviews with key actors in the domain of energy and spatial planning, participation in relevant seminars, desktop research, and discourse analysis of concepts used in these practices. This resulted in a taxonomy that visualizes the diversity of energy projects in Flanders in terms of their spatial strategies and governance structures [24]. The analysis of the discourse surrounding energy transition projects and spatial planning in the region was crucial in selecting concepts that were then further developed via a thorough literature review within the relevant fields where these concepts originated. While this paper will not discuss the taxonomy in detail, it allowed the determination of 11 related design parameters for the spatial and governance dimensions of energy transition practices in dispersedly urbanized regions like Flanders.

The paper discusses theoretical concepts that emerged from the literature review and were considered relevant from the perspective of energy transition practice in the Flemish context of dispersed urbanization. It will systematically address the following concepts from (S)TS and UM, connect these with related concepts from UD, and confront them with the reality of energy transition in Flanders: (1) the energy system as a socio-technical system, (2) the obduracy of energy systems, (3) the conceptualization of space as context in the multilevel perspective, (4) (energy) transitions as a fundamental shift, (5) energy as a metabolic flow, and finally, (6) energy as (socio-political) 'power' (Table 1). These concepts were selected based on the following criteria: (a) they speak about the relation between socio-technical and spatial change, (b) they are adopted by, or have a counterpart in, urban design discourse, and (c) they are essential to understand ongoing energy transition practices in Flanders.

Each of the following sections is organized in a similar way, by (a) focusing and explaining (a set of) (S)TS, UM, or UPE concepts, (b) relating them to UD theories, and (c) confronting them with the realities of physical space and the characteristics of particular energy technologies in the dispersed landscape of Flanders. From this discussion, the paper develops a hypothesis on the interrelationship of 11 parameters for the redesign of energy systems in dispersedly urbanized territories, as shown in Table 1. These parameters will be further operationalized by applying them in action research engaging with ongoing energy transition projects with a clear spatial dimension, notably the case of developing a district heating network in a medium-sized Flemish city. 


\section{Results}

\subsection{Energy as Socio-Technical System, Space as 'Palimpsest', E the Isotropy of the Electricity Network}

Transition studies look at processes of fundamental societal transformation, often related with changes in important subsystems such as the energy, food, or mobility system [29-31]. Some strands study historical transition processes, drawing from historical technology studies or using the perspective of socio-metabolic regimes [32-34]. Others focus on contemporary transitions towards sustainability, studying how to understand and influence system changes based on innovation studies and complex systems theory [35-38]. Being part of the broader 'social studies of technology' or STS, transition thinking conceptualizes the energy system as a socio-technical system. This concept emphasizes the interdependence between technologies and society $[5,39,40]$, and builds upon the 'systems approach' in technology studies, inspired by Hughes' metaphor of the 'seamless web' [41]. Physical (energy) infrastructures are considered part of a system or network that includes heterogeneous components such as regulatory institutions, people, technical standards, 'ways of doing things', policies, etc.

Transition studies are particularly interested in how these systems change. There is an emphasis on the governance and institutional dimension of (energy) transition processes, while attention for the spatial and material aspects of socio-technical innovation has long been limited [5,42]. The recent 'geographical turn' in transition studies has started to address this gap by asking how transition processes differ across geographical contexts and introducing spatial concepts such as location, landscape, territoriality, spatial differentiation, scaling, and spatial embeddedness [42-46]. However, this research mainly analyzes institutional factors of 'place-specificity' such as local technological specialization or market formation, local institutional variation and actor strategies, or regional visions and policies [47]. Only a few studies also understand place-specificity in terms of the physicality and urban morphology of local space, and how it matters to transition processes [48].

Urban design often uses the metaphor of the palimpsest to capture the embeddedness of infrastructure networks within a layered physical urban landscape. Introduced by Corboz, this metaphor refers to the accumulation of historical layers of construction that define and transform urbanized territories [49]. Studying the relations between infrastructure networks, urbanization patterns, and their underlying mechanisms has been particularly important in understanding contemporary forms of dispersed urbanization as they appear in Flanders, the Veneto region, the Northeastern Seaboard of the US, and other urbanized regions around the world [50,51]. By 'unraveling the palimpsest', certain inherent rationalities can be discovered within the seemingly chaotic Flemish territory [52]. The 'nebulous' urbanization of this landscape was shaped by diverse implicit and explicit urbanisms of domains outside formal spatial planning. Particularly the dense networks of transport infrastructure (railway, light-rail, and highway), developed since the end of the 19th century, were crucial elements in the industrialization and urbanization of the region $[12,14,15,53]$. This coevolution of technical networks and urban development was linked with a broader 'system' of long-standing housing practices and policies, economic models, and fiscal structures [18,54,55]. These encouraged home ownership (representing 70.5\% of the housing market today [19]), created a prevalence of single-family dwellings, often in suburban locations, stimulated the settlement of industries across the territory, and supported commuting.

The ubiquitous electricity and gas networks have further facilitated and supported this isotropic condition by making cheap and abundant energy available everywhere in Flanders. Bruggeman shows how provincial and local governments historically stimulated the extension of the electricity network into every corner of the Flemish territory, where it was inscribed into the existing social and spatial fabric [56]. Becoming part of a project of modernization and industrialization of the Flemish region, the electricity network had to support the spatial and socio-economic integration of the territory, and can be understood as a telling example of what has been called the 'modern infrastructure ideal' or the 'networked city' $[8,57,58]$. This illustrates how energy infrastructures are embedded in complex 
social, economic, and technical systems, and in a particular spatial structure, that strongly condition how the energy system might be transformed. A sustainability transition in the energy system then can't be limited to replacing fossil or nuclear energy sources with renewable alternatives, but needs to question the spatial configuration of energy networks, housing practices, and locational choices. That includes rethinking the underlying mechanisms that created and continue to reproduce Flanders' spatial structure, such as the fragmented ownership structure in the housing market, the financial mechanisms that support commuting and suburban living, and the lack of spatial selectivity in the layout of supply networks and energy- efficiency policies.

While the concept of socio-technical systems emphasizes the interdependence of technical systems and society, the palimpsest draws attention to the long-lasting coevolution of infrastructures and spatial form. It allows the understanding of the spatiality of this societal embeddedness as a layering of infrastructure in the dispersedly urbanized landscape. From this realization, it becomes clear that spatial energy transition projects have to work on two opposing dimensions in order to steer the energy transition in a spatially sustainable direction. The question needs to be raised as to what extent the current dominance of spatial isotropy (Table 1, parameter 1) in dispersedly urbanized territories-as it is reinforced by various layers of energy infrastructure and energy policy-needs to be reorganized by introducing spatial selectivity (Table 1, parameter 2) in the energy system. This could also contribute to more compact and bundled—and, as such, more energy-efficient—urbanization patterns.

\subsection{Obduracy, Retro-Active Urbanism, \& the Greening of the Heating System}

STS often characterize infrastructure and spatial structure as obdurate and inert to change. Engaging with this inertia is then an important basis to identify potential pathways of change [4]. Hommels analyzed how this obduracy, or 'resistance to change', is conceptualized in different STS perspectives. She shows that it is associated with diverse dimensions of infrastructures, and recognizes an interactional ('frames'), relational ('embeddedness'), and enduring ('persistent traditions') conception of obduracy [59]. To these mainly immaterial dimensions of obduracy can be added other commonly mentioned factors that complicate change in infrastructures, such as their physicality and spatial embeddedness, material cost (sunk investments), and the time needed for transformation $[36,43]$.

Existing spatial structures and infrastructural arrangements are therefore important factors of path-dependence: current and future states of a system depend on the path of previous states [35]. In contrast with this 'slowness' of spatial change, the speed and unpredictability of technological innovation also forms an important challenge in transition processes. Working within the inherent uncertainty of transitions includes avoiding lock-in, whereby a non-optimal solution would become dominant [60,61].

Other authors have nuanced this view of infrastructures as inert systems, which tend to become 'normalized' or even 'invisible' over time. Furlong emphasizes their 'malleability', showing how 'mediating technologies' can purposefully engage users in the management of infrastructures and introduce a shift from invisibility to 'active consciousness' [62]. This potential is also attributed to digital energy meters and 'smart' technologies that would allow customers to change their energy consumption behavior based on insights about energy offer and price. On a more structural level, Frantzeskaki and Loorbach explore how infrastructural systems might not be inhibitors, but drivers of transitions [4].

Such a perspective resonates with planning and design as inherently transformative practices, where understanding and overcoming the obduracy of existing infrastructure systems is essential. The notion of 'palimpsest' doesn't only emphasize the 'longue durée' of spatial structures, but simultaneously includes the idea of continuous transformation and human intervention. Corboz reads the land not merely as the result of human and natural processes, but also as a product, and explicitly as a project [49]. Thoroughly unraveling the layers of the dispersed landscape has become part of a project of retroactive urbanism [52], a reflection developed particularly in the Italian 
Veneto and in Flanders, that wants to highlight the implicit and explicit 'minimal' rationalities that shape the dispersed territory and serves as a basis for conscious intervention [13,51].

In the context of the Flemish energy transition, the ubiquitous gas network is a crucial factor of path-dependence for the transformation of the heating system. Today, $67 \%$ of households use gas for residential heating, but the network has remaining potential to connect up to $95 \%$ of households [25]. Investments in gas-based appliances and infrastructures are still dominant compared to investments in more sustainable alternatives, continuing Flanders' dependence on imported fossil fuels. The prevalence of high-temperature, individual heating systems, the fragmented ownership structure, and the relatively low building density, form important barriers for the introduction of more sustainable (collective) heating systems. Moreover, if individual solutions such as heating pumps would be widely adopted in the region, this would undermine the future feasibility of collective heating networks in areas where they would be the most appropriate solution. This potential lock-in illustrates the tension between an individual's options for a sustainable heating solution and the dependence on collective decisions for transformation on a larger urban scale. Developing a sustainable alternative for heating then requires a long-term perspective for heating systems that are flexible and open towards spatial and technological evolutions, and allow appropriate heating solutions for different types of spaces and consumers. Insight in the investment cycles and obsolescence of different components of the existing gas system and housing stock are essential to make use of natural moments of replacement and avoid further investment in the 'old' system [25].

Path dependence in the development of energy infrastructure and urbanization leads to obduracy of the energy system. The approach of retroactive urbanism implies that future spatial energy projects should be rooted in the understanding of the long time coevolution between spatial structure and energy infrastructure. Retroactive urbanism allows the unraveling of how logics of path dependence have shaped the spatial configuration of the energy system and incumbent urbanization patterns. In that sense, spatial projects for a sustainable energy transition should identify instances of obsolescence (Table 1, parameter 3) in energy infrastructure and built environment as key opportunities to reshape the energy system in a sustainable way. Secondly, the design of new sustainable energy systems needs to take into account their long-term impact by designing them as open and flexible systems (Table 1 , parameter 4), so that they are less prone to the lock-in effects that come with path-dependency.

\subsection{Space as Context, Space as Agent, \& the Structuring Capacity of Collective Heating Infrastructure}

If energy transitions are to include spatial change, it becomes relevant to examine how transition studies have conceptualized 'space' and 'spatial change' in the widely used Multi-Level-Perspective (MLP). The metaphors in this framework describe different 'levels' of socio-technical systems, but don't necessarily coincide with spatial scales. The 'regime' level represents the dominant technologies, practices, rules, actors, policies, and ways of thinking. It is 'dynamically stable' and usually tends to protect vested interests. This makes radical change difficult and rather leads to incremental and path-dependent change processes, or to optimizing rather than transforming practices [30,35,37]. 'Niches' are the micro level where alternatives or radical innovations emerge. These can influence the regime, particularly when processes at a regime or landscape level create a 'window of opportunity'. The 'landscape' level consists of macroscale political, ecological, and cultural evolutions [63], but also includes existing infrastructures and spatial structures [36]. "The metaphor 'landscape' is used because of the literal connotation of relative 'hardness' and to include the material aspect of society" [36] (p. 913). This view conceptualizes the spatial characteristics of the territory, but also the spatiality of physical infrastructures as a context for transition processes, and thereby places them outside the influence of regime and niche players and thus outside actors' scope of action $[5,63]$.

But for spatial planning and design, having spatial transformation as a central concern, considering the physical 'landscape' merely as a context for processes of change, is a rather limited conceptualization of space. Loeckx and Heynen have brought together different perspectives on the relation between social forces and physical space [64]. Beyond space as a 'receptacle' or result of 
social forces, and space as an 'instrument' for social change (exemplified in modernist approaches to urbanism), they recognize a third and more productive position that conceptualizes space as a 'stage' where social processes play out. The metaphor of the stage refers to the possibility to change the stage setting which in turn influences the action taking place. It recognizes that space both accommodates and frames social transformations [64]. It overcomes technological determinism but at the same time it is not blind to the structuring capacity of built space. The landscape is then not seen as just a 'context', but also as an agent that makes things happen [65].

Designers have tried to understand this structuring capacity retroactively by studying the role of physical infrastructure and natural characteristics (soil, topography, vegetation, water) in the formation of the Flemish dispersed territory, but it has also become the starting point for design and planning strategies that conceive networks and urbanization together. The OrderinF project, for example, takes a regional public transport network as the basis for a transformation of urbanization and mobility patterns [66]. The principle of focusing urbanization around nodes of high connectivity and services has become part of the new Flemish spatial policy plan (BRV), and starts to be translated in concrete projects such as the implementation of transport regions $[67,68]$. Although energy networks have a much 'lighter' physical impact than transport systems, it is worth investigating synergies between the introduction of new energy infrastructures and strategies of urban development to counter sprawl, densification, or collective renovation. The Atelier Diepe Geothermie was a design-based investigation that first explored this potential for collective heating networks distributing deep geothermal energy in the Campine region in Flanders [69]. Collective heating systems, more than electricity networks, require proximity between source and demand. Therefore, the shift to district heating and energy-efficient urbanization based on density and energy exchanges can be mobilized as mutually reinforcing dynamics.

(S)TS conceptualizes space as a mere context in which energy systems take shape, but UD understands space as a stage, highlighting that physical space is not a fixed configuration to which new infrastructures are simply added. To the contrary, it indicates that spatial structure shapes the configuration of new energy infrastructures, but also that new (infra)structures can fundamentally alter urbanized landscapes. For spatial energy transition projects, this means that new energy infrastructures have the capacity to alter or 'structure' (Table 1, parameter 5) urbanization patterns, and this potential should be taken into account in the conception of new energy systems. In cases of dispersed urbanization in particular, 'restructuring' should go in the direction of increasing proximity (Table 1, parameter 6) between urban activities. The fact that particular energy systems also require proximity between source and demand from an efficiency perspective makes such systems interesting candidates for urban design to mobilize the spatially structuring capacities of these infrastructures.

\subsection{Fundamental Shift, Radical Incrementalism, \& the (De)Centralisation of Energy Production and Governance}

TS have reframed 'sustainability' as disruptive to the system as a fundamental and paradigmatic shift [63]. Energy transitions are considered part of radical societal transformations rather than processes of mere technological optimization. Frantzeskaki and Loorbach recognize two pathways for change in infrastructural systems, with incremental change leading either to 'optimization' (potentially creating lock-in or leading to slow radical system change) or to 'fundamental shift' [4]. An important question is then how 'incremental change' can be directed towards a 'fundamental shift' [4], or in terms of urban design, how a local intervention can contribute to systemic change.

Hajer introduced the term radical incrementalism: "radical in terms of result, incremental in terms of the process structure" [70] (p. 47). He also emphasizes that, next to a good understanding of past processes and existing spatial structures, creating a fundamental shift also requires thinking outside existing frameworks. Hajer points to the importance of 'imagination' and the potential of shared imaginaries for the future, but at the same time encourages looking for ways in which 'the future is already present' [71]. This view resonates with TS's interest in niche developments and the approach of 
Transition Management to work with 'frontrunners'. It emphasizes the need to "utilize the opportunities for transformation that are present in an existing system. It joins in with ongoing dynamics rather than forcing changes" [30] (p. 25).

Spatial planning approaches such as Strategic Spatial Planning have developed particular experience in connecting long-term visions with small-scale actions through co-productive processes that involve government, civil society, and private actors [65]. UD methods such as mapping, research-by-design, scenario-building, and design workshops offer powerful tools to visualize the opportunities present in existing territories and to explore alternative futures as a basis for grounded dialogue [72-75]. Several Dutch experiences show how UD can contribute to regional energy visions $[27,28,76-79]$. Such research-by-design explorations have also been used in Flanders to explore future scenarios on a regional scale [22]. But further work is needed to develop them into shared imaginaries that can connect with emerging transition practices and be translated into concrete interventions.

In the dispersed Flemish landscape, the distinction between a centralized system and decentralization is not as straightforward as assumed by Frantzeskaki and Loorbach. For the energy system, they associate the 'optimization' pathway' with 'centralization and efficiency improvements', while 'fundamental shift' is linked with 'decentralization and alternative sources' [4]. But it is important to distinguish between the governance system and the physical configuration of energy systems, which don't necessarily coincide in terms of 'centrality'. The Flemish electricity network, for example, emerged locally and extended into a very decentralized, isotropic spatial structure, while network governance was progressively centralized into intermunicipal energy companies represented in one organization today. The spatial and governance configuration can also differ for different types of energy flows and parts of the system (production, transmission, distribution, consumption). Renewable electricity production can both be spatially centralized (offshore wind) or extremely decentralized (PV), while green heat production benefits from a stronger local embeddedness and proximity to areas of higher demand. As emphasized by Guy and Karvonen, notably collective heating systems fall between micro- and macro strategies and (re-)introduce the importance of the meso-scale of intervention and governance [80].

As the Flemish territory is "the chaotic result of thousands upon thousands of individual decisions" [81] (p. 90), also its transformation will have to be composed of many individual choices for sustainable change, particularly given the fragmented housing ownership structure. But if more structural transformation is to be realized, this individual level of intervention that has been the focus of energy-efficiency policy in Flanders thus far needs to be transcended. A fundamental transformation of the energy system will most likely combine both decentral and centralized elements in a configuration depending on particular spatial conditions and governance structures. Typically dealing with the collective urban scale, UD can play a key role in connecting individual and collective, decentral and larger-scale actions in a systemic approach.

TS conceptualize energy transition as a fundamental transformation of a socio-technical system, but at the same time point to the incrementality of change processes. UD scholars involved in spatial energy projects have coined the term 'radical incrementalism' as a mode of transformation that can result in fundamental change over time. The discipline's experience with coproductive planning and design processes offers interesting tools to imagine and visualize such future visions, but also connects these with local opportunities, small-scale actions, and emerging frontrunners. Fundamentally reimagining energy systems also invites assessing the impact of both centralized and decentralized energy transition solutions-or a combination of both (Table 1, parameter 7). Existing energy policy reproduces the incumbent combination of macro strategies for energy production and centralized network governance in semipublic companies, with micro strategies focusing on home owners for renovation and PV production at household level. However, fundamentally rethinking the configuration of the existing energy system and spatial structure requires interventions that go beyond the household level and act on a relevant collective scale (Table 1, parameter 8). This requires interventions that imagine new 
governance structures and alternative spatial configurations at an in-between level such as the building block, neighborhood, or city-region.

\subsection{Circularity, Designing with Flows, \& Cascading Heat Flows}

Urban metabolism studies conceptualize energy as one of the metabolic flows that sustain urban life. The concept evolved through different disciplines such as human ecology (Chicago School), industrial ecology, urban ecology, and urban political ecology (UPE), each interpreting it in different ways $[6,82,83]$. The industrial ecology approach quantifies the in- and outgoing flows of water, nutrients, energy, and materials in cities. Building upon the work of pioneers like Wolman [84], Howard and Eugene Odum [85], and the Belgian ecologist Duvigneaud, several conceptual models and methods have been developed for this purpose [86]. These studies usually conceptualize the city as a delineated territory that often gets black-boxed, while the spatiality and interrelation of urban flows and urban morphology remains abstract. Notable exceptions are the work of Duvigneaud about Brussels [87], or the Netzstadt project on urbanized landscapes in Switzerland [88], where the study of ecological flows was translated into innovative maps of the urban territory.

An underlying assumption in this field is that the urban metabolism is an unsustainable, linear system, as opposed to the cyclical and more efficient character of natural ecosystems $[6,89,90]$. This perspective values notions of 'circularity' and 'closing cycles', linked with 'relocalization' and 'self-sufficiency'. But conceptualizing the city as a bounded territory risks overlooking the complex interdependencies that have always characterized urban regions in relation to hinterlands nearby or further away [91]. On the other hand, the contribution of more systemic metabolic studies has been to take into account all dimensions of a particular flow. Not only direct energy use, but also indirect or embedded energy in consumption goods or construction materials is then taken into account, for example, in 'consumption-based UM' or life-cycle analysis for buildings or neighborhoods [92-94]. UM studies also allow the understanding of how energy use is distributed across different energy carriers such as electricity, gas, fuel oil, etc. The quantification of flows then has to serve as a basis for policy and design to develop more sustainable metabolisms. But it has proven difficult to accurately reflect urban complexity in such technical calculations, and even relatively exhaustive studies don't necessarily result in operative concepts or effective policy [95]. Moreover, these quantitative approaches have been critiqued as technocratic views that lack a critical perspective and reduce sustainability to a technical optimization of existing systems [6].

Metabolism thinking and ecology have influenced urban design practice and discourse in diverse ways and moments, for example, in the work of scholars like Geddes (late 19th century) [96], McHarg, or Tjallingii (since the 60s and 70s) [97,98]. Diverse urban designers have conceived urban models that give a spatial expression to a system of flows, either metaphorically, or by taking infrastructures that accommodate various flows as these models' spatial backbone. Strands of ecological and landscape urbanism have revived an interest in ecological processes and flows $[7,99,100]$. Recently, the urban metabolism metaphor has become central in the debate again, with several projects mapping urban metabolisms and 'designing with flows' [101-104]. These approaches visualize and synopsize complex metabolic systems in relation to their spatial context and make complex data intelligible for a broader audience [73]. But often they do not engage with the technicality of metabolic systems and underestimate the socio-political complexity of transforming them. It therefore remains difficult to translate these systemic analyses into design proposals or projects.

Introducing 'circularity' in the Flemish energy system and relocalizing energy production poses particular challenges. Truly 'circular' energy systems can't exist, because during any process, entropy increases and exergy (work capacity) is destroyed $[90,105]$. In the case of energy, the 'Trias Energetica' [106] and van den Dobbelsteen's adaptation, the New Stepped Strategy [107], are used as a more operational approach towards sustainable energy flows. The steps proposed by van den Dobbelsteen emphasize (1) reducing energy consumption, (2) reusing waste energy streams, (3a) producing remaining demand from renewables, and ( $3 b)$ using waste as food. This strategy 
also inspired energy-conscious design strategies such as the REAP (Rotterdam Energy Approach and Planning) and LES (Leidraad Energetische Stedenbouw) using a multi-scalar approach [108-110]. Reusing waste energy streams is possible mainly in the case of heat flows, where 'circularity' can be replaced by the more accurate concept of 'cascading': using high temperatures where necessary (e.g., for industrial processes), and reusing residual heat in steps for processes that need lower temperatures (e.g., residential heating) [105]. The fragmentation and functional mixity of the Flemish landscape offer opportunities for such energy exchanges between different types of functions. On the other hand, the integration of large energy production facilities such as wind turbines or solar parks is more difficult, because renewable sources have a lower 'energy density' than conventional energy sources. They require more space, which is challenging to find in a densely inhabited region where available space is limited [22]. Important factors are landscape characteristics and the visual, environmental, and spatial impact of new energy infrastructures, but also public support [111-114]. Moreover, each type of flow (electricity, heat, fuel) or energy source (particularly biomass, household waste) should be studied at its relevant spatial scale in terms of energy efficiency, economic viability, carbon impact, and governance. As Flanders currently imports around 90\% of its energy [21], relocalizing energy production might also result in strategic and economic advantages, according to the different forms of ownership and governance used. The question of self-sufficiency in the energy system, and on what scale it should be approached, is therefore very relevant in contexts of dispersed urbanization and in the Flemish context in particular.

UM studies conceptualize energy as a metabolic flow and link sustainability to the objective of circularity and 'closing cycles'. UD has rediscovered a tradition of 'designing with flows', developing a systemic approach to urban metabolism by spatializing and visualizing flows of energy, materials, water, or waste. But the theoretical ideal of self-sufficiency or circularity within a bounded area ignores the fact that cities have always depended on other regions for (energy) resources. The large spatial footprint of renewable energy production compared to fossil or nuclear energy further complicates this question, particularly in densely urbanized territories like Flanders. Therefore, 'circularity' immediately raises the issue of 'scale' (Table 1, parameter 9) and the need for planners and designers of energy transition projects to consider the relevant spatial scale of a particular (energy) flow. They need to address the connection of governance systems and physical infrastructures across multiple spatial scales in order to (re)think the mechanisms at work in a specific spatial context. Moreover, perfect circularity is impossible in the case of energy, because its quality ('exergy') diminishes during any process where work is performed. However, the alternative concept of cascading (Table 1, parameter 10), is an interesting way to operationalize the exergy principle by revalorizing energy flows that would otherwise be wasted. It also has important spatial implications as it requires coupling urban activities based on their energy profile, making it a promising concept to organize spatial activities more efficiently, particularly in a context of dispersed urbanization.

\subsection{Energy as 'Power', Co-Production, \& Energy as Common}

Where quantitative metabolism approaches have been criticized to 'depoliticize' metabolic flows and disregard the social, political, and historical dimensions of urban metabolism, STS and UPE have developed more critical approaches to urban infrastructures.

TS recognize that the transformation of the energy system is not just a technological project but involves the emergence of new actors and shifts in power relations, inevitably leading to conflict and contestation. Several authors have drawn attention to these socio-political aspects of transforming urban infrastructures $[5,61,115,116]$, and have studied and conceptualized the forms of power at work in such transformative processes $[117,118]$.

Social studies of networked infrastructure have also shown that they are not 'neutral engineers' stuff'. They show how the creation of the networked city, from the mid-nineteenth century, was part of a project of spatial, socio-economic, and metabolic integration, or the 'modern infrastructural ideal' $[8,57,58]$. In contrast, studies of contemporary phenomena emphasize the exclusionary impact of 
infrastructure reconfigurations. Graham \& Marvin's 'splintering urbanism' thesis illustrates how processes of liberalization, unbundling, and bypassing can lead to exclusion and embed social inequalities in the design, materiality, and functioning of technical networks [58].

UPE has reframed urban metabolism as a fundamentally political concept, using it as a critical lens to understand the relation between capital, power, and nature $[6,9,119]$. It interprets urban metabolism as a number of interconnected physical and social processes, studying not only the material aspects of metabolic flows, but also their social, cultural, and political meaning [6]. The metabolic perspective is then used to unveil uneven power relations and inequalities in the 'socio-political production of nature', and its translation into urban infrastructures.

These critical analyses are important but have rarely suggested institutional or governance improvements or proposed positive alternatives [39]. Coutard and others nuanced this 'alarming' view, emphasizing the need for a 'politics of hope' and a better understanding of alternative, context-sensitive stories of contestation [120,121].

But (energy) transitions are also opportunities to question the socio-political shaping of urban infrastructure more fundamentally, and rethink the interdependence of people and systems of collective consumption. Key choices in energy transitions are "not so much about different fuels or technologies, but between different social, economic and political arrangements built in combination with new energy technologies" [122] (p. 139). The satisfaction of social needs was traditionally seen as a question for the state. But the erosion of the welfare state and the rise of an increasingly 'energetic' society of empowered citizens and entrepreneurs [70] call to rethink this conventional role.

The 'commons' framework offers an inspiring alternative. Commons-thinking foregrounds collective governance practices and forms of ownership that go beyond the market-state dichotomy $[123,124]$. Energy is then not seen as a commodity but as a common good, and individuals not as mere consumers but as citizens that claim the right to participation or ownership. An increasing number of practices show how citizens can take control over systems of energy production and distribution [125-128].

This also calls for a more critical engagement of urban planning with the political forces at work in (energy) transition processes, and a better understanding of the socio-economic impact of different potential outcomes. The discipline has so far mainly focused on visualizing the spatial impact of new energy systems while the governance and political dimension has remained underexplored. UD can build upon its experience with design and planning as a process of co-production between public and private actors and civil society, to connect the technical and spatial complexity of urban infrastructures with its socio-political dimensions $[65,129,130]$. As suggested by Sijmons, urban design methods such as research-by-design and scenario building should go beyond technical discussions and make socio-political questions and diverging ideological positions explicit [28].

In the Flemish energy field, new actors are emerging and the role of traditional actors has been called into question. The governance of electricity and gas distribution networks in the region has historically been centralized into the hands of intermunicipal companies (having the Flemish municipalities as their main shareholders). But certain voices from civil society question their potential role in the energy transition because of their lack of transparency and democratic accountability, and inherent conflicts of interest $[131,132]$. As a regime player these intermunicipal companies could play a key role in the transformation of the energy system, but they also have strong vested interests and sunk investments in the existing networks. Citizen energy cooperatives have developed projects for renewable energy production, claiming wind and sun as common resources, but also for reducing energy demand through collective renovations, and for the implementation of district heating systems. They argue for democratic and financial participation of citizens in energy infrastructure, emphasize the potential benefits of this participation for local economies, and are often successful in raising public support for new energy infrastructures $[128,133]$. Such 'commoning' approaches in the field of energy mirror similar developments in other domains such as food and housing, where a diversity of 'collective' housing models such as cohousing and Community Land Trusts are emerging [134]. 
Both STS and UPE have critically assessed the role of (political) power relationships in the transformation of energy systems and infrastructures. This calls for UD to broaden its conception of urban development as a process of co-production, to include not only spatial but also socio-political dimensions of spatial energy projects explicitly in a participatory approach. This raises the societal acceptance of new energy infrastructure projects and supports the democratic legitimacy of the spatial (energy) solutions proposed. Commons theory adds to the issue of a democratic decision-making process, the dimension of a long-term sustained collective management of energy as a common resource rather than a commodity. As such, the commons (Table 1, parameter 11) provide a good lens to assess the socio-political aspects of spatial energy projects by combining the dimensions of a shared physical resource (the energy system and its infrastructures), a democratic decision-making process, and a long-term collective management of the resource. Moreover, commons-based institutions could jointly govern not only the energy system, but also other (physical) resources such as housing.

\section{Discussion. Spatial and Governance (Re)Design Parameters for Energy Systems in Dispersed Territories}

The case of energy transition in the Flemish nebular city shows how place-specificity, in the sense of spatial morphology and urban structure, matters in sustainability transitions. Table 1 lists a number of spatial (re)design parameters for energy systems in dispersedly urbanized territories, and for the Flemish context in particular. The research reveals that a transformation of the energy system is inextricably linked with the need to rethink incumbent, unsustainable spatial patterns. In the case of dispersed territories like Flanders, the question is how this energy-intensive form of urbanization can be reimagined in terms of 'proximity'. That doesn't mean taking the 'compact city' as an ideal, but finding a more sustainable balance between spreading and concentration. If spatial planning wants to be effective in guiding spatial structure, it needs to understand and mobilize the inherent spatial logics of domains that influence urbanization, such as housing and transport policies, but also, as this paper argues, energy policies. Notably, a 'rebundling' of urban development in relation to sustainable mobility and energy systems is the way forward.

The Flemish case also illustrates how different energy flows or infrastructures (electricity, gas, heat, fuel) have a different relation with spatial structure, depending on the importance of proximity between source and demand, and on the spatial selectivity of the network. Once a network is distributed isotropically over the territory, it loses its spatially (re)structuring potential. Moreover, each flow has to be analyzed at the right spatial scale, going beyond abstract notions of 'circularity' or 'decentralization', and recognizing the limits of becoming self-sufficient within a certain urban territory.

The switch towards a sustainable heating system, with the introduction of collective heating networks and the potential dismantling of the ubiquitous gas system, then emerges as a particularly relevant opportunity to mobilize the energy transition as a lever to revalorize 'proximity' in urban development. More than electricity and gas networks, collective heating systems benefit from proximity between source and demand and are more feasible in denser urban areas where complementary urban functions are mixed. The spatial logics of these networks can therefore be mutually reinforcing with the principles of energy-conscious urban design and sustainable mobility. This requires a spatially selective development of collective heating systems in areas where sustainable urban development is possible and desired. Another challenge for urban design is to understand and work with the spatial consequences of technical concepts such as 'cascading', for example, by identifying opportunities to exchange heat between different urban functions and rethinking locational choices based on the energy profile of specific activities.

Integrating the transformation of the energy system into spatial planning and policy does not only require a consideration of the spatial configuration and prerequisites but also of the governance dimensions of various sustainable energy solutions. Therefore, Table 1 also lists a number of concepts related to the governance of the energy system. Interventions that mobilize the restructuring capacity of energy infrastructure can only be developed at a collective scale and therefore need to go beyond 
the individualism in the Flemish housing and energy system. Similar to emerging collective housing practices, the introduction of new energy infrastructures opens opportunities for 'commons'-inspired forms of governance. Developing more democratic and inclusive forms of governance is particularly relevant in the case of collective systems such as district heating. These are embedded in local spatial structures, living cultures, and economies, and strongly depend on public support and social change for their implementation.

Table 1. Overview of relations between theoretical concepts from (S)TS, UM, UPE, and UD, and (re)design parameters regarding spatial configuration ${ }^{*}$ and governance ${ }^{\circ}$ in dispersed territories.

\begin{tabular}{|c|c|c|c|}
\hline Disciplinary Field & Theoretical Concept(s) & $\begin{array}{l}\text { Urban Design } \\
\text { Concept(s) }\end{array}$ & $\begin{array}{c}\text { Design Parameters In Dispersedly } \\
\text { Urbanized Territories }\end{array}$ \\
\hline (S)TS & $\begin{array}{l}\text { Energy as socio-technical } \\
\text { system [41] }\end{array}$ & Space as palimpsest [49] & $\begin{array}{c}\text { Isotropy * } \\
\text { Spatial selectivity * } \\
\text { E.g., Historical evolution of the electricity network }\end{array}$ \\
\hline (S)TS & $\begin{array}{l}\text { Obduracy Path } \\
\text { dependence Lock-in [59] }\end{array}$ & $\begin{array}{c}\text { Retroactive urbanism } \\
{[51,52]}\end{array}$ & $\begin{array}{l}\text { 3. Obsolescence as opportunity *० } \\
\text { 4. Open and flexible systems *० } \\
\text { E.g., Greening the heating system }\end{array}$ \\
\hline (S)TS & Space as context $[5,36]$ & Space as stage/agent [64] & $\begin{array}{c}\text { 5. Structuring capacity infrastructure * } \\
\text { 6. Proximity } \\
\text { Eg. (Geothermal) collective heating infrastructure }\end{array}$ \\
\hline TS & $\begin{array}{l}\text { Incremental change and } \\
\text { Fundamental shift }[4,31]\end{array}$ & $\begin{array}{l}\text { Radical incrementalism } \\
\text { Urban Trialogues } \\
{[65,70,130]}\end{array}$ & $\begin{array}{c}\text { 7. (De-) centralization }{ }^{* 0} \\
\text { 8. Individual/collective interventions } * 0 \\
\text { E.g., (De-)centralisation of energy production and } \\
\text { network governance }\end{array}$ \\
\hline MS & $\begin{array}{l}\text { Energy as metabolic flow } \\
\text { Circularity }[84-86,95]\end{array}$ & $\begin{array}{l}\text { Designing with flows } \\
\text { [102-104] }\end{array}$ & $\begin{array}{c}\text { 9. Multi-scalarity *० } \\
\text { 10. Cascading * } \\
\text { E.g., (Low temperature) district heating }\end{array}$ \\
\hline UPE & $\begin{array}{c}\text { Energy as 'power' } \\
{[8,9,61,122]}\end{array}$ & Co-production $[65,129]$ & $\begin{array}{l}\text { 11. Energy as common }{ }^{\circ} \\
\text { E.g., Citizen energy cooperatives }\end{array}$ \\
\hline
\end{tabular}

\section{Conclusions}

This paper has brought together complementary theoretical perspectives on the transformation of technical infrastructures from transition studies, metabolism studies, and urban design theory. On the one hand, the metaphor of UM recently became central in UD debate and produced new approaches to visualizing and spatializing metabolic flows. But for these approaches to become useful in concrete projects, they need to engage more deeply with the materiality and politics of urban change. This paper highlights the value of concepts from TS and the broader STS-field, where the notions of urban infrastructures as 'socio-technical systems', 'obduracy', and of 'fundamental shift' offer a more useful framework to understand the complexity of energy transitions. They capture both the technical material and the socio-political dimension of transforming the energy system, and point to the need for urban planning and design to address this multidimensional embeddedness in approaching the energy transition as a spatial project. On the other hand, the urban design perspective broadens the conceptualization of space merely as 'context', and emphasizes the spatially structuring potential of technical infrastructures. It invites the thinking of energy transition as part of a multifaceted process of spatial change.

The conceptual framework outlined in this paper allows theorizing such an integrated view of energy transition as a process of spatial and socio-political transformation. However, while it has become clear in theory that the energy transition is about more than replacing fossil fuels with renewable alternatives, realizing its full transformative potential requires a context-specific reading of spatial challenges and opportunities and a societal debate that recognizes more explicitly the socio-political questions that are at stake. This paper therefore proposes 11 design parameters describing the spatial and governance dimensions of energy transition strategies that are particularly relevant in contexts of dispersed urbanization. These parameters can be operationalized to analyze, design, or evaluate spatial energy transition practices and spatial development projects. They will be tested and validated in the next phase of this research project in an action-research approach designing 
different scenarios for the future development of heating systems in Flanders. The aim is to explore how urban planning and design processes can move beyond technical discussions of energy transition to include spatial transformation of unsustainable settlement patterns and a shift towards democratic and inclusive forms of governance.

Acknowledgments: The research for this paper is funded by the Vrije Universiteit Brussel. This includes funding to publish in open access. The authors would also like to thank inputs on earlier versions of this paper by prof. Huw Thomas and prof. Stefanie Dühr at the AESOP Ph.D. workshop 2017 in Aveiro, and appreciate the insightful feedback of two anonymous referees

Author Contributions: G.J. and M.R. jointly identified the disciplinary fields and concepts reported in this article. G.J. conducted the literature study and gathered the empirical data on the Flemish spatial context and energy transition case. G.J. analyzed the concepts and proposed a first organization of the results, which was further refined in collaboration with M.R. G.J. wrote the paper, re-editing and integrating various suggestions with regards to the structure and presentation of the argument by M.R., who also wrote concluding paragraphs for Section 3.

Conflicts of Interest: The authors declare no conflict of interest.

\section{References and Notes}

1. Habitat III Issue Papers-18-Urban Infrastructure and Basic Services, Including Energy; UNOPS, UN-Habitat: New York, NY, USA, 2015.

2. Habitat III Thematic Meeting on Sustainable Energy and Cities; UN General Assembly: New York City, NY, USA, 2016.

3. Kona, A.; Melica, G.; Bertoldi, P.; Rivas Calvete, S.; Koffi, B.; Iancu, A.; Zancanella, P.; Janssens-Maenhout, G.; Dallemand, J.F. Covenant of Mayors in Figures: 8-Year Assessment; Joint Research Centre: Luxembourg, 2017.

4. Frantzeskaki, N.; Loorbach, D. Towards governing infrasystem transitions, reinforcing lock-in or facilitating change? Technol. Forecast. Soc. Chang. 2010, 77, 1292-1301. [CrossRef]

5. Bulkeley, H.; Castàn Broto, V.; Maassen, A. Low-carbon Transitions and the Reconfiguration of Urban Infrastructure. Urban Stud. 2014, 51, 1471-1486. [CrossRef]

6. Castàn Broto, V.; Allen, A.; Rapoport, E. Interdisciplinary Perspectives on Urban Metabolism. J. Ind. Ecol. 2012, 16, 851-861. [CrossRef]

7. Belanger, P. Landscape Infrastructure: Urbanism beyond Engineering. In Infrastructure, Sustainability and Design; Spiro, G., Pollalis, A., Ramos, S., Schodek, D., Eds.; Routledge: New York, NY, USA, 2012; pp. 276-316, ISBN 978-0-415-89316-9.

8. Coutard, O.; Rutherford, J. Beyond the Networked City: Infrastructure Reconfigurations and Urban Change in the North and South; Routledge studies in urbanism and the city; Routledge: London, UK; New York, NY, USA, 2016, ISBN 978-1-138-79682-9.

9. Heynen, N.; Kaika, M.; Swyngedouw, E. In the Nature of Cities, Urban Political Ecology and the Politics of Urban Metabolism; Routledge: London, UK; New York, NY, USA, 2006, ISBN 978-0-415-36828-5.

10. Shannon, K.; Smets, M. The Landscape of Contemporary Infrastructure; nai010 Publishers: Rotterdam, The Netherlands, 2010.

11. Dupuy, G. Urban Networks—Network Urbanism; van Schaick, J., Klaasen, I., Eds.; Techne Press: Amsterdam, The Netherlands, 2008; ISBN 978-90-8594-019-7.

12. De Block, G.; Polasky, J. Light railways and the rural-urban continuum: Technology, space and society in late nineteenth-century Belgium. J. Hist. Geogr. 2011, 37, 312-328. [CrossRef]

13. Ryckewaert, M. The Minimal Rationality of Dwelling Patterns in Flanders' Nevelstad. OASE Tijdschr. Voor Archit. 2002, 60, 49-62.

14. Ryckewaert, M. Building a Hybrid Highway System. Road Infrastructure as an Instrument of Economic Urbanization in Belgium. Transfers 2012, 2, 59-86. [CrossRef]

15. Van Acker, M. From Flux to Frame. Designing Infrastructure and Shaping Urbanization in Belgium; Leuven University Press: Leuven, Belgium, 2014; ISBN 978-90-5867-958-1.

16. Van Broeck, L. Presented at the Klimaattop Vlaanderen, Ghent, Belgium, 19 April 2016.

17. Boussauw, K.; Witlox, F. Introducing a commute-energy performance index for Flanders. Transp. Res. Part Policy Pract. 2009, 43, 580-591. [CrossRef] 
18. Bervoets, W.; Heynen, H. The obduracy of the detached single family house in Flanders. Int. J. Hous. Policy 2013, 13, 358-380. [CrossRef]

19. Winters, S.; Ceulemans, W.; Heylen, K.; Pannecoucke, I.; Vanderstraeten, L.; Van den Broeck, K.; De Decker, P.; Ryckewaert, M.; Verbeeck, G. Wonen in Vlaanderen Anno 2013: De Bevindingen uit het Grote Woononderzoek 2013 Gebundeld; Steunpunt Wonen: Leuven, Belgium, 2015.

20. Vanneste, D.; Thomas, I.; Vanderstraeten, L. The spatial structure(s) of the Belgian housing stock. J. Hous. Built Environ. 2008, 23, 173-198. [CrossRef]

21. Argusrapport. Energie voor Morgen: Krijtlijnen van een Duurzaam Energiesysteem; Argus: Tielt, Belgium, 2014; p. 118.

22. Labo Ruimte. Energielandschap Vlaanderen; Report for Team Vlaams Bouwmeester, Vlaamse Landmaatschappij, Ruimte Vlaanderen, VITO; Posad, 3E, Universiteit Gent, Resource Design; Labo Ruimte: Brussels, Belgium, 2015; p. 212.

23. Van Esch, L.; Meynaerts, E.; Vermeiren, K.; Uljee, I.; Janssen, L.; Guisson, R.; Engelen, G.; Hoes, H.; Robeyn, N. Hernieuwbare EnergieAtlas Vlaamse Gemeenten; VITO, TerraEnergy: Departement Leefmilieu, Natuur en Energie: Brussels, Belgium, 2016.

24. Juwet, G. De ruimtelijke dimensie van energietransitie in Vlaanderen: Het structurerend potentieel van collectieve energieprojecten. In Plandag 2017: Gedeelde Ruimte: Gebundelde Papers en Bijdragen; Bouma, G., Ed.; PDD, BNSP, VRP: Gent, Belgium, 2017.

25. Cyx, W. Studieopdracht: Naar een Vergroening van de Warmtevoorziening voor Huishoudens in Vlaanderen; Bond Beter Leefmilieu: Brussels, Belgium, 2017.

26. Raeymaekers, K. Editorial: Het wordt warm onder onze voeten. Ruimte 2017, 35.

27. Sijmons, D. Landschap en Energie, Ontwerpen voor Transitie; nai010 Publishers: Rotterdam, The Netherlands, 2014, ISBN 978-94-6208-112-3.

28. Sijmons, D. Energie E Ruimte, Een Nationaal Perspectief; for Vereniging Deltametropool; FABRICations, $\mathrm{H}+\mathrm{N}+\mathrm{S}, \mathrm{POSAD}$, Studio Marco Vermeulen. NRGlab Wageningen Universiteit. Vereniging Deltametropool: Rotterdam, The Netherlands, 2017.

29. Block, T.; Paredis, E. Transitiemanagement: De Januskop van duurzaamheid in Vlaamse steden en van het gangbare transitiedenken. In Duurzame en Creatieve Steden: De Stad als Motor van de Samenleving; Agentschap voor Binnenlands Bestuur: Brussel, Belgium, 2012; pp. 97-128.

30. Rotmans, J.; Kemp, R.; Van Asselt, M. More evolution than revolution: Transition management in public policy. Foresight 2001, 3, 15-31. [CrossRef]

31. Fischer-Kowalski, M.; Rotmans, J. Conceptualizing, Observing, and Influencing Social-Ecological Transitions. Ecol. Soc. 2009, 14, 1-18. [CrossRef]

32. Haberl, H.; Fischer-Kowalski, M.; Krausmann, F.; Martinez-Alier, J.; Winiwarter, V. A Socio-metabolic Transition towards Sustainability? Challenges for another Great Transformation. Sustain. Dev. 2011, 19, 1-14.

33. Geels, F. Technological transitions as evolutionary reconfiguration processes: A multi-level perspective and a case-study. Res. Policy 2002, 31, 1257-1274. [CrossRef]

34. Geels, F. The Dynamics of Transitions in Socio-technical Systems: A Multi-level Analysis of the Transition Pathway from Horse-drawn Carriages to Automobiles (1860-1930). Technol. Anal. Strateg. Manag. 2005, 17, 445-476. [CrossRef]

35. Rotmans, J.; Loorbach, D. Complexity and Transition Management. J. Ind. Ecol. 2009, 13, 184-196. [CrossRef]

36. Geels, F. From sectoral systems of innovation to socio-technical systems, Insights about dynamics and change from sociology and institutional theory. Res. Policy 2004, 33, 897-920. [CrossRef]

37. Smith, A.; Voss, J.-P.; Grin, J. Innovation studies and sustainability transitions: The allure of the multi-level perspective and its challenges. Res. Policy 2010, 39, 435-448. [CrossRef]

38. Geels, F.; Schot, J. Typology of sociotechnical transition pathways. Res. Policy 2007, 36, 399-417. [CrossRef]

39. Monstadt, J. Conceptualizing the political ecology of urban infrastructures: Insights from technology and urban studies. Environ. Plan. A 2009, 41, 1924-1942. [CrossRef]

40. Verbong, G.; Geels, F. The ongoing energy transition: Lessons from a socio-technical, Multi-level analysis of the Dutch Electricity system (1960-2004). Energy Policy 2007, 35, 1025-1037. [CrossRef]

41. Hughes, T.P. The Seamless Web: Technology, Science, Etcetera, Etcetera. Soc. Stud. Sci. 1986, 16, $281-292$. [CrossRef] 
42. Faller, F. A practice approach to study the spatial dimensions of the energy transition. Environ. Innov. Soc. Transit. 2016, 19, 85-95. [CrossRef]

43. Bridge, G.; Bouzarovski, S.; Bradshaw, M.; Eyre, N. Geographies of energy transition: Space, place and the low-carbon economy. Energy Policy 2013, 53, 331-340. [CrossRef]

44. Coenen, L.; Benneworth, P.; Truffer, B. Toward a spatial perspective on sustainability transitions. Res. Policy 2012, 41, 968-979. [CrossRef]

45. Coenen, L.; Truffer, B. Places and Spaces of Sustainability Transitions: Geographical Contributions to an Emerging Research and Policy Field. Eur. Plan. Stud. 2012, 20, 367-375. [CrossRef]

46. Hodson, M.; Marvin, S. Can cities shape socio-technical transitions and how would we know if they were? Res. Policy 2010, 39, 477-485. [CrossRef]

47. Hansen, T.; Coenen, L. The geography of sustainability transitions: Review, synthesis and reflections on an emergent research field. Environ. Innov. Soc. Transit. 2015, 17, 92-109. [CrossRef]

48. Castàn Broto, V. Energy landscapes and urban trajectories towards sustainability. Energy Policy 2017, 108, 755-765. [CrossRef]

49. Corboz, A. The Land as Palimpsest; SAGE: Newcastle upon Tyne, UK, 1983.

50. Dehaene, M. From the nebular city to the horizontal metropolis: Notes on the continued urbanization of the Flemish territory. In A Landscape Perspective on Urbanism; Uyttenhove, P., Dehaene, M., Eds.; Academia Press: Gent, Belgium, 2015.

51. Viganò, P.; Secchi, B.; Fabian, L. Water and Asphalt, the Project of Isotropy; UFO: Explorations of Urbanism; The University of Chicago Press: Chicago, IL, USA, 2016; ISBN 978-3-906027-71-5.

52. Dehaene, M.; De Meulder, B. Hybrid figures in the dispersed city: Towards a retroactive urbanism for the Flemish urban landscape. Archit. Urban. 2003, 6, 126-131.

53. De Block, G. Planning Rural-Urban Landscapes: Railways and Countryside Urbanisation in South-West Flanders, Belgium (1830-1930). Landsc. Res. 2014, 39, 542-565. [CrossRef]

54. De Decker, P. Understanding housing sprawl: The case of Flanders, Belgium. Environ. Plan. A 2011, 43, 1634-1654. [CrossRef]

55. Ryckewaert, M. Building the Economic Backbone of the Belgian Welfare State. Infrastructure, Planning and Architecture 1945-1973; 010 Publishers: Rotterdam, The Netherlands, 2011; ISBN 978-90-6450-751-9.

56. Bruggeman, D.; Dehaene, M. Urban questions in the countryside? Urbanization and the collective consumption of electricity in early twentieth-century Belgium. Plan. Perspect. 2017, 32, 309-332.

57. Kaika, M.; Swyngedouw, E. Fetishizing the Modern City: The Phantasmagoria of Urban Technological Networks. Int. J. Urban Reg. Res. 2000, 24, 120-138. [CrossRef]

58. Graham, S.; Marvin, S. Splintering Urbanism; Routledge: London, UK, 2001, ISBN 978-0-415-18965-1.

59. Hommels, A. Studying Obduracy in the City: Toward a Productive Fusion between Technology Studies and Urban Studies. Sci. Technol. Hum. Values 2005, 30, 323-351. [CrossRef]

60. David, P.A. Clio and the economics of QWERTY. Am. Econ. Rev. 1985, 75, 332-337.

61. Meadowcroft, J. What about the politics? Sustainable development, transition management, and long term energy transitions. Policy Sci. 2009, 42, 323-340.

62. Furlong, K. Small technologies, big change: Rethinking infrastructure through STS and geography. Prog. Hum. Geogr. 2010, 35, 460-482. [CrossRef]

63. Paredis, E.; Block, T. Transitiepraktijk van de Vlaamse Overheid: Meer dan een schijnbeweging? Vlaams Tijdschr. Voor Overheidsmanag. 2015, 1, 11-19.

64. Heynen, H. Space as receptor, instrument or stage. Notes on the interaction between spatial and social constellations. Int. Plan. Stud. 2013, 18, 342-357. [CrossRef]

65. Loeckx, A.; Shannon, K.; Tuts, R.; Verschuere, H. Urban Trialogues: Visions_Projects_Co-Productions. Localising Agenda 21; UN Habitat: Nairobi, Kenya, 2004; ISBN 978-92-1-131709-1.

66. Blondia, M. Een Onderzoek naar het Ruimtelijk Sturend Potentieel van een Geïntegreerd Regionaal Openbaar Vervoersproject voor de Vlaamse Nevelstad \& Een Netwerk van Verknoopte Corridors als Strategie voor de Transformatie van Mobiliteits- en Verstedelijkingspatronen. Doctoral Thesis, KULeuven, Leuven, Belgium, September 2014.

67. Verachtert, E.; Mayeres, I.; Poelmans, L.; Van der Meulen, M.; Vanhulsel, M.; Engelen, G. Ontwikkelingskansen op Basis van Knooppuntwaarde en Nabijheid Voorzieningen; VITO for Ruimte Vlaanderen: Brussel, Belgium, 2016.

68. Witboek. Beleidsplan Ruimte Vlaanderen; Departement Omgeving: Brussels, Belgium, 2016. 
69. Departement Ruimte Vlaanderen. Atelier Diepe Geothermie; Report for Team Vlaams Bouwmeester; Departement Ruimte Vlaanderen: Brussels, Belgium, 51N4E; 2015.

70. Hajer, M. The Energetic Society. In Search of a Governance Philosophy for a Clean Economy; PBL Netherlands Environmental Assessment Agency: The Hague, The Netherlands, 2011; ISBN 978-90-78645-78-8.

71. Hajer, M. The Power of Imagination; Utrecht University: Utrecht, The Netherlands, 2017.

72. Cox, V. Investigating Urban Design Workshops in Flanders: Researching Designerly Research. Doctoral Thesis, KULeuven, Leuven, Belgium, March 2014.

73. Marin, J. Reinterpreting the territory's resourcefulness. In Urbanism and Urbanization 2018: On Reproduction: Re-Imagining the Political Ecology of Urbanism; Ghent University: Ghent, Belgium, 2018; pp. 141-156.

74. Schreurs, J.; Kuhk, A. Hybride narratieven in regionale toekomstverkenningen: Verkenning van de complementariteit van Ontwerpmatig Onderzoek en Scenario-Bouw. In Plannen van de Toekomst: Gebundelde Papers en Bijlagen Plandag 2011; Stichting Planologische Studiedagen: Brussel, Belgium, 2011; pp. 333-352.

75. Viganò, P. Les Territoires de l'urbanisme, le Projet Comme Producteur de Connaissance; MétisPresses: Genève, Switzerland, 2016, ISBN 978-2-940406-88-3.

76. Stremke, S.; Van Kann, F.; Koh, J. Integrated Visions (Part I): Methodological Framework for Long-term Regional Design. Eur. Plan. Stud. 2012, 20, 305-319. [CrossRef]

77. Stremke, S.; Koh, J.; Neven, K.; Boekel, A. Integrated Visions (Part II): Envisioning Sustainable Energy Landscapes. Eur. Plan. Stud. 2012, 20, 609-626. [CrossRef]

78. Van Bolhuis, W.; de Willigen, J.; Eekhof, J.M.; Dorsman, E.; de Haan, J. Denkbeelden voor een Slimme Energiestad; Atelier Stadsbouwmeester Groningen: Groningen, The Netherlands, 2016.

79. Leduc, W.R.W.A.; Van Kann, F.M.G. Spatial planning based on urban energy harvesting toward productive urban regions. J. Clean. Prod. 2013, 39, 180-190. [CrossRef]

80. Guy, S.; Karvonen, A. District heating comes to Ecotown: Zero carbon housing and the rescaling of UK energy provision. In Beyond the Networked City: Infrastructure Reconfigurations and Urban Change in the North and South; Coutard, O., Rutherford, J., Eds.; Routledge studies in urbanism and the city; Routledge: London, UK; New York, NY, USA, 2016; pp. 72-93.

81. De Meulder, B.; Schreurs, J.; Cock, A.; Notteboom, B. Patching up the Belgian Landscape. OASE: Tijdschrift voor Architectuur 1999, 52, 78-113.

82. Newell, J.P.; Cousins, J.J. The boundaries of urban metabolism: Towards a political-industrial ecology. Prog. Hum. Geogr. 2014, 39, 702-728. [CrossRef]

83. Wachsmuth, D. Three Ecologies: Urban Metabolism and the Society-Nature Opposition. Soc. Q. 2012, 53, 506-523. [CrossRef]

84. Wolman, A. The Metabolism of Cities. Sci. Am. 1965, 213, 178-193. [CrossRef]

85. Odum, H.T. Environment, Power and Society; John Wiley \& sons: New York, NY, USA, 1971, ISBN 978-0-471-65275-5.

86. Holmes, T.; Pincetl, S. Urban Metabolism Literature Review; UCLA Institute of the Environment, Centre for Sustainable Urban Systems: Brussels, Belgium, 2012.

87. Duvigneaud, P.; Denayer-De Smet, S. L'écosystème Urbain Bruxellois. In Productivité Biologique en Belgique; Editions Duculot: Gembloux, Belgium, 1977; Volume Travaux de la section Belge du programme biologique international; pp. 608-613.

88. Oswald, F.; Baccini, P. Netzstadt: Designing the Urban; Birkhäuser: Basel, Switzerland; Boston, MA, USA; Berlin, Germany, 2003, ISBN 978-3-7643-6963-7.

89. McDonough, W.; Braungart, M. Cradle to Cradle: Remaking the Way We Make Things; North Point Press: New York, NY, USA, 2002; ISBN 978-0-86547-587-8.

90. Barragán-Escandón, A.; Terrados-Cepeda, J.; Zalamea-León, E. The Role of Renewable Energy in the Promotion of Circular Urban Metabolism. Sustainability 2017, 9, 2341. [CrossRef]

91. Katsikis, N. On the Geographical Organization of World Urbanization. Available online: http:/ / urbantheorylab. net/site/assets/files/1126/geographical_organization_landscape_1.pdf (accessed on 24 March 2017).

92. Athanassiadis, A.; Christis, M.; Bouillard, P.; Vercalsteren, A.; Crawford, R.H.; Khan, A.Z. Comparing a territorial-based and a consumption-based approach to assess the local and global environmental performance of cities. J. Clean. Prod. 2016, 1-12. [CrossRef] 
93. Allacker, K.; De Troyer, F.; Trigaux, D.; Geerken, T.; Debacker, W.; Spirinckx, C.; Van Dessel, J.; Janssen, A.; Delem, L.; Putzeys, K. Sustainability, Financial and Quality Evaluation of Dwelling Types SuFiQuaD; Universiteit Leuven, VITO: Brussels, Belgium, 2011.

94. Allacker, K.; Trigaux, D.; De Troyer, F. Model for the environmental impact assessment of neighbourhoods. WIT Trans. Ecol. Environ. 2014, 181, 103-114.

95. Kennedy, C.; Pincetl, S.; Bunje, P. The Study of Urban Metabolism and Its Applications to Urban Planning and Design. Environ. Pollut. 2011, 159, 1965-1973. [CrossRef] [PubMed]

96. Geddes, P. The Valley Section from Hills to Sea. Available online: http://habitat.aq.upm.es/b/n45/apged.en.html (accessed on 24 March 2017).

97. McHarg, I. Design with Nature; Natural History Press: New York, NY, USA, 1969, ISBN 978-0-471-11460-4.

98. Tjallingii, S. Ecopolis: Strategies for Ecologically Sound Urban Development; Backhuys Publishers: Leiden, The Netherlands, 1995, ISBN 90-73348-34-X.

99. Mostafavi, M.; Doherty, G. Ecological Urbanism, revised ed.; Lars Müller Publishers: Zürich, Switzerland, 2016, ISBN 978-3-03778-189-0.

100. Waldheim, C. The Landscape Urbanism Reader; Princeton Architectural Press: New York, NY, USA, 2006, ISBN 978-1-56898-439-1.

101. Tilly, N.; Klijn, O.; Borsboom, J.; Looije, M. Urban Metabolism: Sustainable Development of Rotterdam; IABR - International Architecture Biennale Rotterdam: Rotterdam, The Netherlands, 2014.

102. Fernández, J.; Ferrão, P. Sustainable Urban Metabolism; The MIT Press: Cambridge, MA, USA, 2013, ISBN 978-0-262-01936-1.

103. Ibanez, D.; Katsikis, N. New Geographies_Grounding Metabolism; Harvard University Press: Cambridge, MA, USA, 2014, ISBN 978-1-934510-37-7.

104. Hajer, M.; Dassen, T. Smart about Cities: Visualising the Challenge for 21st Century Urbanism; nai010 Publishers: Rotterdam, The Netherlands, 2014, ISBN 978-94-6208-148-2.

105. Stremke, S.; van den Dobbelsteen, A.; Koh, J. Exergy landscapes: Exploration of second-law thinking towards sustainable landscape design. Int. J. Exergy 2011, 8, 148-174. [CrossRef]

106. Lysen, E. The Trias Energetica: Solar Energy Strategies for Developing Countries. In Proceedings of the Eurosun Conference, Freiburg, Germany; 1996.

107. Van den Dobbelsteen, A. Towards closed cycles-New strategy steps inspired by the Cradle to Cradle approach. In Proceedings of the 25th Conference on Passive and Low Energy Architecture, Dublin, Ireland, 22-24 October 2008.

108. Van den Dobbelsteen, A.; Tillie, N.; Doepel, D.; Joubert, M.; De Jager, W.; Mayenburg, D. Towards $\mathrm{CO}_{2}$-neutral urban planning: Presenting the Rotterdam Energy Approach and Planning (REAP). J. Green Build. 2009, 4, 103-112.

109. Van den Dobbelsteen, A.; Tillie, N.; Kürschner, J.; Mantel, B.; Hakvoort, L. The Amsterdam guide to energetic urban planning. In Proceedings of the Management and Innovation for a Sustainable Built Environment, Amsterdam, The Netherlands, 20-23 June 2011.

110. Vandevyvere, H.; Stremke, S. Urban planning for a renewable energy future: Methodological challenges and opportunities from a design perspective. Sustainability 2012, 4, 1309-1328. [CrossRef]

111. Pasqualetti, M.J. Morality, space and the power of wind-energy landscapes. Geogr. Rev. 2000, 90, 381-394. [CrossRef]

112. Walker, G. What are the barriers and incentives for community-owned means of energy production and use? Energy Policy 2008, 36, 4401-4405. [CrossRef]

113. Wüstenhagen, R.; Wolsink, M.; Bürer, M.J. Social acceptance of renewable energy innovation: An introduction to the concept. Energy Policy 2007, 35, 2683-2691. [CrossRef]

114. Sansen, J. Gemeenschapsparticipatie in windenergie: Een antwoord op de groeiende tegenstand? Oikos 2015, 73, 94-104.

115. Byrne, J.; Toly, N. Energy as a Social Project: Recovering a Discourse. In Transforming Power: Energy, Environment, and Society in Conflict; Byrne, J., Toly, N., Glover, L., Eds.; Transaction Publishers: Piscataway, NJ, USA, 2006; pp. 1-32, ISBN 978-1-4128-0514-8.

116. Coutard, O.; Rutherford, J. Energy transition and city-region planning: Understanding the spatial politics of systemic change. Technol. Anal. Strateg. Manag. 2010, 22, 711-727. [CrossRef] 
117. Avelino, F.; Rotmans, J. Power in Transition: An Interdisciplinary Framework to Study. Eur. J. Soc. Theory 2009, 12, 543-569. [CrossRef]

118. Hoffman, J.; Loeber, A. Exploring the Micro-politics in Transitions from a Practice Perspective-The Case of Greenhouse Innovation in the Netherlands. J. Environ. Policy Plan. 2016, 18, 692-711. [CrossRef]

119. Heynen, N. Urban political ecology I: The urban century. Prog. Hum. Geogr. 2013, 1-7. [CrossRef]

120. Coutard, O.; Guy, S. STS and the City, Politics and Practices of Hope. Sci. Technol. Hum. Values 2007, 32, 713-734. [CrossRef]

121. Coutard, O. Placing splintering urbanism: Introduction. Geoforum 2008, 39, 1815-1820. [CrossRef]

122. Miller, C.A.; Iles, A.; Jones, C.F. The Social Dimensions of Energy Transitions. Sci. Cult. 2013, 22, $135-148$. [CrossRef]

123. Harvey, D. The Future of the Commons. Radic. Hist. Rev. 2011, 109, 101-107. [CrossRef]

124. Mattei, U. The strategy of common assets: Providing direct access to social justice by renewing common sense: The state, the market and some preliminary questions about the commons. In Redefining and Combating Poverty: Human Rights, Democracy and Common Assets in Today's Europe; Trends in Social Cohesion Series; Council of Europe Publishing: Strasbourg, France, 2012; pp. 307-324.

125. Becker, S.; Naumann, M.; Moss, T. Between coproduction and commons: Understanding initiatives to reclaim urban energy provisino in Berlin and Hamburg. Urban Res. Pract. 2017, 10, 63-85. [CrossRef]

126. Seyfang, G.; Haxeltine, A. Growing grassroots innovations: Exploring the role of community-based initiatives in governing sustainable energy transitions. Environ. Plan. C Gov. Policy 2012, 30, 381-400. [CrossRef]

127. Shove, E.; Walker, G. CAUTION! Transitions ahead: Politics, practice and sustainable transition management. Environ. Plan. A 2007, 39, 763-770. [CrossRef]

128. Vansintjan, D. De Energietransitie naar Energiedemocratie, "Power to the People"; Rescoop: Berchem, Belgium, 2016.

129. Albrechts, L. Reframing Strategic Spatial Planning by Using a Coproduction Perspective. Plan. Theory 2013, 12, 46-63. [CrossRef]

130. Vervloesem, E.; De Meulder, B.; Loeckx, A. Stadsvernieuwingsprojecten in Vlaanderen-(2002-2011); Academic and Scientific Publishers: Brussel, Belgium, 2012.

131. Walraven, J. VREG stelt vragen bij ambitieuze fusieplannen Kennis. Apache, May 2017, 7.

132. Willems, T. De Eandis-deal: een gemiste kans voor energiedemocratie. De Gids, 2016, 38-44.

133. Willems, T. Coöperatief ondernemen met windenerie. Waarom Vlaanderen nood heeft aan een winddecreet. Oikos 70, 2014, 5-16.

134. Aernouts, N.; Ryckewaert, M. Reconceptualizing the "Publicness" of Public Housing: The case of Brussels. Soc. Incl. 2015, 3, 17-30. [CrossRef]

(c) 2018 by the authors. Licensee MDPI, Basel, Switzerland. This article is an open access article distributed under the terms and conditions of the Creative Commons Attribution (CC BY) license (http://creativecommons.org/licenses/by/4.0/). 